\title{
Congruent and Metaphorical Coding Based on Grammatical Mood and Speech Function in Oprah Winfrey's Talk Show
}

\section{Lilian, Syahron Lubis, and Nurlela}

Fakultas IImu Budaya, Universitas Sumatera Utara, Medan, Indonesia

\section{Abstract}

This research is to examine the use of Mood and Speech Function in Oprah Winfrey's Talk Show. Oprah Winfrey's Talk Show is chosen because it is an American syndicated talk show that aired nationally for 1986 to 2011. It is highly influential and many of its topics have penetrated into the American pop-cultural consciousness. The analysis of this research based on Eggins, S and Slade (1997:184) which includes Congruent and Incongruent Realization of Speech Function. This paper concerns on the analysis of Congruent and Incongruent of Mood and Speech Function in Oprah Winfrey's Talk Show. This uses descriptive research method, in which the data are described

Corresponding Author: Lilian

lilianmuchtar08@gmail.com

Received: 1 July 2019

Accepted: 18 July 2019

Published: 31 July 2019

Publishing services provided by

Knowledge E

(c) Lilian et al. This article is

distributed under the terms of

the Creative Commons

Attribution License, which

permits unrestricted use and

redistribution provided that the

original author and source are credited

Selection and Peer-review unde the responsibility of the AICLL 2019 Conference Committee. systematically to get an accurate and factual result. The data used in this study are the clauses containing of grammatical mood and speech function used by Oprah Winfrey's Talk Show. The finding describes that as a talk show host, Oprah Winfrey, has a power to express Incongruent or Metaphorical Coding in Realization of Speech Function. It also to analyze how the mood and speech function realized in the conversation in Oprah Winfrey's Talk Show.

Keywords: Congruent, Incongruent, Metaphorical Coding, Mood, Speech Function

\section{Introduction}

Language is fundamental aspects for human beings in living. One of the main goals of language is to communicate with people and to understand them. People speak to intend a specific purpose, for example to convey a message, to express his feelings, to ask and to apologize Language is also influenced by many aspects because we use it around social life for example nature of society, kind of people (social role), context, education, family background and attitudes. According to Geoffery Leech (1974) language has five functions such as Informational, Expressive, Directive, Aesthetic, and Phatic. 
Informational function concentrates on the message and gives information based on truth and value. For example, when we see something, we will have an opinion about it. "The car is expensive" or "It is very crowded". In Expressive function, the speaker or the writer try to express his feelings, to reflex the impression and to give a clear image for the personality of the speaker or the writer such as poetry and literature. In Directive function, it has function to influence the behavior or attitudes of others such as commands an request. We can see this example: "I want a cup of coffee". It could be used to show the condition of the speaker or writer express the feeling but in other expression, it could be a person asks someone to give him a cup of coffee. The fourth function is Aesthetic function, which is the use of language for the sake of the linguistic artifact itself, and for $n$ purpose. It can have at least as much to do with conceptual as with affective meaning. The fifth function is the Phatic function, which has function of keeping in a good repair. It also can say that this function is used for formal talks. This function which relates to this study. For example, people who meet with other accidentally in a place sometime start talking about something unimportant for the sake of communication.

To use language, people need a pattern to make the understandable messages, so that it conveys clearly, called a grammar. Grammar is a theory of language of how language is put together and how it works. Gerot and Wignell (1994:4) state that: there are three grammars which have had a major influence on schools in this century". These are as traditional grammar, formal grammar and functional grammar.

Traditional grammar aims to describe the grammar of standard English by comparing it with Latin. Formal grammar is concerned to describe the structure of individual sentences. Functional grammar views language as resource for making meaning. This grammar attempts to describe language in actual use and focuses on text and their context. They concern not only with the structures but also with those meaning constructions. Functional grammar called functional linguistics considers function or meanings and semantics as the bases of human language and communicative activity.

Halliday (1985: xii) states “The fundamental components meaning in language are functional components. All languages are organized around three main kinds of meanings such as ideational meanings, interpersonal meanings and textual meanings". These principal components of meaning or metafunctions are added in the structure of clause.

Ideational Meanings are meanings about phenomena-about things such as living and non-living, abstract and concrete and about goings on such as what it happens. These meanings are realized in wordings through Participants, Processes, Circumstances, Meanings of this kind are most centrally influenced by the field of discourse. 
Interpersonal Meanings are meanings which express a speaker's attitude and judgments. These are meanings for acting upon with others. Meanings are realized in wordings through what is called Mood and Modality. They are most centrally influenced by tenor of discourse.

Textual Meanings express the relation of language to its environment, including both the verbal environment, what has been said or written before (co-text) and the nonverbal, situational environment (context). These meanings are realized through patterns of Theme and Cohesion. Textual meanings are most centrally influenced by mode of discourse.

In this modern life, both language and technology grow rapidly. People use language to communicate one another by using modern technology and service. In spoken language besides taking a direct conversation by face to face, people use media as telephone or video call to make a conversation. In conveying news and information also has grown, not only in written but also spoken. Television is as one of media in transferring information provide many program to entertain and to inform the society. It can be said that the growth of language along with the growth of technology. This research focuses on talk show as one of program television consisted of discussion various topics.

A talk show or chat show is a television programming or radio programming genre in which one person (or group of people) discusses various topics put forth by a talk show host. Usually, guests consist of a group of people who are learned or who have great experience in relation to whatever issue is being discussed on the show for that episode. Other times, a single guest discusses their work or area of expertise with a host or co-hosts. A call-in show takes live phone calls from callers listening at home, in their cars, etc. Sometimes, guests are already seated but are often introduced and enter from backstage. There have been many notable talk show hosts; in many cases, the shows have made their hosts famous.

In this research, the data is "Oprah Winfrey Talk Show", which is in the spoken language. The data is the chosen clauses used in the talk show between the presenter and the interviewees. The researcher chooses this data which is Oprah Winfrey Talk Show because this show was highly influential, and many of its topics have penetrated into the American pop-cultural consciousness. Winfrey used the show as an educational platform, featuring book clubs, interviews, self-improvement segments, and philanthropic forays into world events. The show did not attempt to profit off the products it endorses; it had no licensing agreement with retailers when products were promoted, nor did the show make any money from endorsing books for its book club. 
(https://en.wikipedia.org/wiki/The_Oprah_Winfrey_Show).

By understanding all these function, especially in Directive function and the characteristics of spoken language, this research aims to analyze the use of the sentence in congruent and incongruent, called metaphorical coding like Directive function meaning in a talk show chosen. In this case, this study uses systemic functional grammar that is mood and speech function theory which is developed by Halliday.

According to Gerot and Wignell (1994:25), "the mood element consists two parts, they are subject, which is realize by a nominal group and finite element, which is part of the residue. A clause thus consists of Mood + Residue.

According to Halliday (2004:111), when we come to look closely at statements and questions, and at the various responses to which these naturally give rise, we find that in English they are typically expressed by means of a particular kind of grammatical variation: variation which extends over just one part of the clause, leaving the remainder unaffected.

Mood element has a clearly defined semantic function: it carries the burden of the clause as an interactive event. So it remains constant, as the nub of the proposition, unless some positive step is taken to change it. What is the component that is being bandied about in this way? It is called the Mood element, and it consists of two parts: (1) the Finite operator, which is part of a verbal group, and (2) the Subject, which is a nominal group.

According to Gerot and Wignell (1994:22), there are options of speech functions:

\section{Offer}

The speaker gives the hearer some goods or services and the speaker inherently invites the hearer to receive those goods and services.

For example: 'Would you mind telling me the truth?'

\section{Command}

The speaker demands the hearer some goods and services and the hearer thereby invited to give that service or provide the goods. For example: "Let's go back to five years ago when it was first announced to us, the public, that you were going to be leaving "The Tonight Show." 


\section{Statement}

The speaker gives the hearer some information and the speaker inherently is inviting the hearer to receive the information. For Example: "We don't want to lose him"

\section{Question}

The speaker demands the hearer some information and the speaker inherently is inviting the hearer to give that information.

For example: "How did that come about?"

Sometimes there are many incongruent realizations of speech functions that can be found in informal dialogue. These phenomena occur when a speech function is not realized by the predicated mood type; we can see it from the table below:

TABLE 1: Congruent and Incongruent Realization of Speech Function.

\begin{tabular}{l|c|c|}
\hline Speech Function & $\begin{array}{c}\text { Congruent Clause } \\
\text { Mood }\end{array}$ & Incongruent Clause Mood \\
\hline Statement & Declarative & Tagged declarative \\
\hline $\begin{array}{l}\text { Question } \\
\text { Interrogative }\end{array}$ & $\begin{array}{c}\text { Modulated declarative } \\
\text { Imperative }\end{array}$ & $\begin{array}{c}\text { Modulated interrogative, } \\
\text { declarative }\end{array}$ \\
\hline Offer & $\begin{array}{c}\text { Modulated } \\
\text { interrogative }\end{array}$ & \begin{tabular}{l} 
Imperative declarative \\
\hline Source: Eggins and Scade (1997:184)
\end{tabular} \\
\hline
\end{tabular}

\section{Literature Review}

Other research has provided in many journals. There are similar previous researches that related to researchers' research topic. Therefore, the research uses these researches as the developing of ideas. Three similar previous researches below are: Some of the research has analyzed mood and speech functions. The first is an International Journal of English Lingustics by Leonard A. Koussouhon \& Ashani M. Dossoumou. This journal entitles Analyzing Interpersonal Meaning through Mood and Modality in Kaine Agary's Yellow-Yellow from Critical Discourse and Womanist Perspective. The findings data revealed by the interpersonal meaning analysis are discusses against the blackdrop of critical discourse analysis and womanist theory. The discussion contended that, despite the blend of monologic and dialogic organization of the novel, Kaine Agary has tried to portray the sociological schisms making up the daily life of young 
girls in the oil-resourced region of Nigeria. More importantly, the authoress has shown women's determination and character goes against this developmental stream flow by impregnating her. The mood and modality choices operated show some kind of power and hierarchy relations and conflicting ideologies between Sisi, Lolo, Zilafeya and Admiral. The discursive interpretation eventually found that the interpersonal meaning hidden authorial ideology behind Kaine Agary's fictional text is geared towards a prowomen social change for a more balanced African society. This is, of course, the gist priorities and great tropical issues calling for urgent response at this time.

The second research is a thesis of Post-Graduated student of State University of Medan, Indari, Ayu (2011) that is Realization of Speech Function in Mood of the Susilo Bambang Yudhoyonos (SBY) Speeches. She found that from two kinds of SBY's speeches namely Bombings and SMS bermasalah that Speech function in both of the speeches is realized into the form of Mood: Declarative.

The third research is a journal by Jumino Suhadi (2015) that is Interpersonal Metaphor of Mood Applied to Some Verses of the Holy Al-Qur'an. He found that some verses of the Holy Al-Qur'an use the transference of mood in conveying messages: some indicative moods are expressed in the interrogative and imperative, some imperative moods in the indicative and interrogative, and some interrogative moods in the indicative and imperative. The writer maintains that Halliday's theory of Interpersonal Metaphor can be justified as an adequate linguistic theory.

This research is hoped to complete the research and the journal before. This analyzed not only Mood and Speech Function but also Congruent and Incongruent or Metaphorical Coding conversations in a talk show that is Oprah Winfrey.

\section{Research Method}

The research method in this study covers research design, unit of analysis, source of data, method of data collection and method of data analysis.

The researcher uses descriptive research method, in which the data were described systematically to get an accurate and factual result. The data analysis in the research uses qualitative analysis, Qualitative research is a procedure of research which produces descriptive data in the form of written words or oral words about the object that is observed. This method is used to analyze and to describe the mood and speech functions uses in Oprah Winfrey's Talk Show.

The data used in this study consist of the clauses such as grammatical mood and speech function used by Oprah Winfrey as the host in Oprah Winfrey's Talk Show. 
The data of this research are written. The data consist of the script of Oprah Winfrey's Talk Show taken from https://deadline.com/2010/01/complete-transcript-of-jay-leno-onoprah-23916/. The data were chosen because Oprah Winfrey is one of the best female host in the world and also this show was highly influential, and many of its topics have penetrated into the American pop-cultural consciousness. Winfrey used the show as an educational platform, featuring book clubs, interviews, self-improvement segments, and philanthropic forays into world events.

Data collection is a systematic procedure and standardization to obtain the necessary data (Nazir:2011). Data collection techniques used in this study are seeing and note taking techniques. Seeing technique used to scrutinize to the language used. The term of scrutinizing here is not only related to the use of language orally, but also the use of language in writing (Mahsun:2005). The seeing technique in this research uses the advanced techniques in the form of note taking technique. Note taking technique is to note several forms that are relevant for this research from the use of language in writing (Mahsun: 2005). The technique will be done with these following steps:

1. Downloading and watching the script and the record Oprah Winfrey's Talk Show.

2. Identifying the grammatical mood and speech function Oprah Winfrey's Talk Show.

3. Identifying congruent and metaphorical coding of the script based on grammatical mood and speech function.

4. Classifying grammatical mood and speech function of clauses used by host in Oprah Winfrey's Talk Show.

5. Classifying congruent and metaphorical coding of the script based on grammatical mood and speech function.

6. Analyzing the use of congruent and metaphorical coding used by the host in Oprah Winfrey's Talk Show.

Analyzing the characters using congruent and metaphorical coding used by the host in Oprah Winfrey's Talk Show.

Data analysis techniques used in this study are Interactive Model Techniques by Miles \& Huberman. According to Miles \& Huberman (Miles:1994) in this model there are three components of analysis, namely data reduction, data display and conclusion drawing (verification). Data analysis will be done with the following steps:

1. Identifying each clauses based on grammatical mood and speech function in Oprah Winfrey's Talk Show. 
2. After being identified, the next step is to classifying them based on the kinds of grammatical mood and speech function used by the host in Opray Winfrey's Talk Show

3. After determining the kinds of grammatical mood and speech function, it is made a congruent and metaphorical coding based on interpersonal function.

4. Classifying the use of congruent and metaphorical coding the host in Opray Winfrey's Talk Show.

5. Describing the use of congruent and metaphorical coding the host in Opray Winfrey's Talk Show.

Drawing conclusions and giving suggestions.

\section{Result and Discussion}

By analyzing between Oprah Winfrey as the host when interviewing with Jay Leno as the guest, it can be observed that she sometimes used Congruent and Metaphorical Coding. It is used metaphorical coding when she wanted to emphasize the real and sentimental question from the guest. This table below showed:

\begin{tabular}{|c|c|c|c|}
\hline Oprah Winfrey's Clause & Mood & Speech Function & Realization \\
\hline $\begin{array}{l}\text { Okay. So let's go back to five years } \\
\text { ago when it was first announced to } \\
\text { us, the public, that you were going } \\
\text { to be leaving "The Tonight Show." }\end{array}$ & Imperative & Command & Congruent \\
\hline How did that come about? & Interrogative & Statement & Congruent \\
\hline This is $2004 ?$ & Declarative & Question & Metaphorical \\
\hline $\begin{array}{l}\text { Had there been a prior discussion } \\
\text { that at some point, you would hand } \\
\text { the show over to Conan or that... }\end{array}$ & Declarative & Statement & Congruent \\
\hline ...you'd have the show for a while? & Declarative & Question & Metaphorical \\
\hline $\begin{array}{l}\text { That the franchise would be handed } \\
\text { over? }\end{array}$ & Declarative & Question & Metaphorical \\
\hline $\begin{array}{l}\text { When they came into your office, } \\
\text { they, NBC executives, come to your } \\
\text { office, your show is number one in } \\
\text { nighttime and tell you that you're } \\
\text { going to be moving out in five years }\end{array}$ & Declarative & Statement & Congruent \\
\hline what is your first reaction to that? & Interrogative & Question & Congruent \\
\hline $\begin{array}{l}\text { So in your mind this happened or } \\
\text { that move happened, because } \\
\text { Conan wanted that spot? }\end{array}$ & Declarative & Question & Metaphorical \\
\hline
\end{tabular}




\begin{tabular}{|c|c|c|c|}
\hline Oprah Winfrey's Clause & Mood & Speech Function & Realization \\
\hline $\begin{array}{l}\text { Even though your show was number } \\
\text { one at the time? }\end{array}$ & Declarative & Question & Metaphorical \\
\hline So that broke your heart? & Declarative & Question & Metaphorical \\
\hline $\begin{array}{l}\text { Okay. So were you planning at the } \\
\text { end of that five-year period, } 2009 \text {, } \\
\text { you were-what were you going to } \\
\text { do? }\end{array}$ & Interrogative & Question & Congruent \\
\hline $\begin{array}{l}\text { Did you think you'd go to another } \\
\text { network? }\end{array}$ & Interrogative & Question & Congruent \\
\hline $\begin{array}{l}\text { Mm-hmm. So at what point did the } \\
\text { NBC executives come to you and } \\
\text { say, }\end{array}$ & Interrogative & Question & Congruent \\
\hline $\begin{array}{l}\text { "We want you to do your show in } \\
\text { prime time?" }\end{array}$ & Declarative & Question & Congruent \\
\hline
\end{tabular}

\section{Conclusion}

The higher intellectual of each person is, the better the choice of clause is used. Oprah Winfrey, as the host of the talk show, used congruent and metaphorical coding in her clause. In conveying the show, she must give the most interesting style in getting the audience's attraction. One of the ways is by using metaphorical coding in delivering her statement, question and command. Metaphor is one of the ways of communication among the speakers. Metaphor shows the power, intellect, ability in communicating. Furthermore, this research can be used to learn and to study meanings such as interpersonal meaning and grammatical mood and speech function. Hopefully, this research is able to solve the problem in learning interpersonal meanings and to add information for the readers which the best way in doing interviewing, dialogue or conversation.

\section{References}

[1] C. Hartnett. (1986). Static and Dynamic Cohesion: Signal of Thinking in Writing" in Couture, Barbara Functional Approachess to Writing Research Perspectives. London: Prances Pronter.

[2] Eggins, Suzanne. (1994). An Introduction to Systemic Functional Linguistics. London: Pinter Publisher Ltd.

[3] Eggins, S., Slade, D. (1997). Analysing Casual Conversation. London: Cassell.

[4] Farkhan M. (2007). Proposal Penelitian Bahasa dan Sastra. Jakarta: Cella Jakarta. 
[5] Gerot, Linda and Wignell, Peter. (1994). Making Sense of Functional Grammar, First Edition. Queensland. Australia: Antipodean Educational Enterprises.

[6] Halliday, M.A.K. (1985) An Introduction to Functional Grammar. London: Edward Arnold.

[7] Halliday, M.A.K. (1994). An Introduction to Functional Grammar. $2^{\text {nd }}$ edn. London: Edward Arnold.

[8] Halliday, M.A.K. Matthiesses. (2004). An Introduction to Functional Grammar. $3^{\text {rd }}$ edn. London: Edward Arnold.

[9] Leech Geoffrey. (1974). Semantics. Suffolk: Richard Clay (The Chaucer Press) Ltd: PT Raja Grafindo Persada

[10] Martin, J.R. (1992). English Text: System and Structure. Philadelpia: John Benjamins Publishing Company.

[11] Martin, Matthiessen and Clare. (1997). Working with Functional Grammar. London: Arnold, a member of the Hodder Headline Group.

[12] Mahsun. (2005) Metode Penelitian Bahasa Tahapan Strategi, metode, dan Tekniknya. Jakarta: PT Raja Grafindo Persada.

[13] Miles, MB \& Huberman. (1994). "Qualitative data analysis: An expanded sourcebook," Evaluation and Program Planning.

[14] Nazir, M.(2011). Metode Penelitian. Jakarta: Ghalia Indonesia.

[15] Renkema. (1993). Discourse Studies: An Introductory Textbook. Amsterdam: John Benjamins Publishing Company.

[16] Thompson, Geoff. (1996). Introducing Functional Grammar. London: Edward Arnold. 